\title{
An economical and safe procedure to synthesize 2-hydroxy-4-pentynoic acid: A precursor towards 'clickable' biodegradable polylactide
}

\author{
Quanxuan Zhang ${ }^{* 1}$, Hong Ren ${ }^{2,3}$ and Gregory L. Baker ${ }^{1}$
}

\section{Full Research Paper}

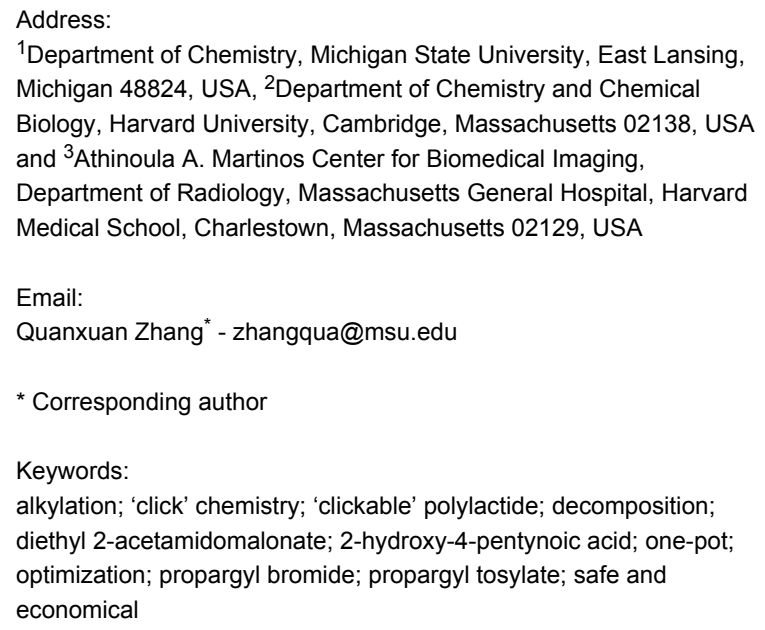

${ }^{1}$ Department of Chemistry, Michigan State University, East Lansing, Michigan 48824, USA, ${ }^{2}$ Department of Chemistry and Chemical Biology, Harvard University, Cambridge, Massachusetts 02138, USA and ${ }^{3}$ Athinoula A. Martinos Center for Biomedical Imaging, Department of Radiology, Massachusetts General Hospital, Harvard Medical School, Charlestown, Massachusetts 02129, USA

\section{Email:}

Quanxuan Zhang* - zhangqua@msu.edu

* Corresponding author

\section{Keywords:}

alkylation; 'click' chemistry; 'clickable' polylactide; decomposition; diethyl 2-acetamidomalonate; 2-hydroxy-4-pentynoic acid; one-pot; optimization; propargyl bromide; propargyl tosylate; safe and economical

Beilstein J. Org. Chem. 2014, 10, 1365-1371. doi:10.3762/bjoc. 10.139

Received: 26 March 2014

Accepted: 17 May 2014

Published: 17 June 2014

Associate Editor: D. Y.-K. Chen

(c) 2014 Zhang et al; licensee Beilstein-Institut. License and terms: see end of document.

\begin{abstract}
2-Hydroxy-4-pentynoic acid (1) is a key intermediate towards 'clickable' polylactide which allows for efficient introduction of a broad range of pendant functional groups onto polymers from a single monomer via convenient 'click' chemistry with organic azides. The incorporation of various pendant functional groups could effectively tailor the physicochemical properties of polylactide. The reported synthesis of 1 started from propargyl bromide and ethyl glyoxylate. However, both of starting materials are expensive and unstable; especially, propargyl bromide is shock-sensitive and subjected to thermal explosive decomposition, which makes the preparation of 1 impractical with high cost and high risk of explosion. Herein, we report a simple, economical and safe synthetic route to prepare 1 using cheap and commercially available diethyl 2-acetamidomalonate (4) and propargyl alcohol. The desired product 1 was obtained via alkylation of malonate $\mathbf{4}$ with propargyl tosylate followed by a one-pot four-step sequence of hydrolysis, decarboxylation, diazotization and hydroxylation of propargylic malonate $\mathbf{5}$ without work-up of any intermediate.
\end{abstract}

\section{Introduction}

Aliphatic polyesters, in particular polylactide (PLA), are now widely used for biomedical applications, such as surgery sutures [1], implants for bone fixation [2], drug delivery vehicles [3,4] and tissue engineering scaffolds [5] because of their excellent biocompatibility, biodegradability and mechanical properties. However, due to low solubility of PLA in water, applications of PLA in an aqueous environment have been greatly restricted. In addition, the lack of functional group diversity in the back- 
bones and side chains of PLA makes further modification difficult. Therefore, the introduction of a variety of functional groups to PLA is highly desirable to modulate the physicochemical properties of the resulting polymers, such as hydrophilicity.

Recently, numerous $\alpha, \omega$-chain end functionalized PLAs have been reported through ring-opening polymerization of lactide by judicious choice of initiating alcohols and further post-polymerization modification of $\omega$-chain end hydroxy groups [6-8] Moreover, the appending functionalities along PLA backbones provide great opportunities for altering physical and/or chemical properties of PLAs. PLA with pendent functional groups can be achieved by ring-opening polymerization of functional lactide monomers, post-polymerization modification, or a combination of these two approaches. The appending hydroxy [9], carboxyl [10], poly(ethylene glycol) (PEG) [11-14], allyl [15], azido [16] and acetylene [17] functionalities on PLA backbones have been reported and offered great opportunities for covalent post-polymerization modification of PLAs.

Among various functional groups, acetylene functionalized PLA has attracted much attention [17-19]. By having a single functional lactide monomer, it allows for facile placement of a broad range of pendant functional groups onto polymers via convenient 'click' reaction with organic azido molecules without PLA backbone degradation [17]. 'Click' chemistry [20], which is copper(I)-catalyzed 1,3-dipolar cycloaddition of azides and alkynes, has been developed and utilized in recent years as a powerful synthetic strategy because of its high selectivity and excellent tolerance to different functional groups and reaction conditions. Our group has prepared the first 'clickable' PLA using 2-hydroxy-4-pentynoic acid (1) as a precursor
(Scheme 1) and studied 'click' modification of acetylene functionalized PLA [17]. One new family of water-soluble and temperature responsive biodegradable PLA material with tunable lower critical solution temperature (LCST) in a range from 25 to $65{ }^{\circ} \mathrm{C}$ was obtained after 'click' grafting with a mixture of alkyl and PEG azides. Starting from the same precursor 1 [18], Yu and coworkers have prepared a novel graft polymerdrug conjugate (GPDC) with potent cancer inhibitor paclitaxel linked to PLA backbones. The GPC results indicated that GPDC released paclitaxel moieties from polymer complexes in phosphate buffer solutions under physiological $\mathrm{pH}$ of 5.5 and 7.4 , suggesting its potential clinical application. More recently, Coumes and coworkers have prepared acetylene functionalized PLAs from precursor 1 and 'click' modification of the resulting PLAs with PEG azides provided amphiphilic graft copolymers which form nanorod aggregates in water [19].

The results discussed above indicate the great power to tune physicochemical properties of PLA by 'click' modification of acetylene functionalized PLA. Precursor $\mathbf{1}$ is the key intermediate in the preparation of these 'clickable' PLAs. It was synthesized in $40 \%$ overall yield via hydrolysis of ester 2 which was generated by Reformatsky-type reaction of propargyl bromide with fresh distilled ethyl glyoxylate in the presence of activated zinc (Scheme 1) [17]. However, the synthesis of precursor 1 used propargyl bromide and ethyl glyoxylate as starting materials, both of which are expensive and unstable. These starting materials must be stabilized by toluene and purified before reaction. Flash column chromatography is also required in the process. Besides its high cost, propargyl bromide is shocksensitive and subjected to thermal explosive decomposition [2123], which makes the preparation of 1 via this method impractical with high risk of explosion.

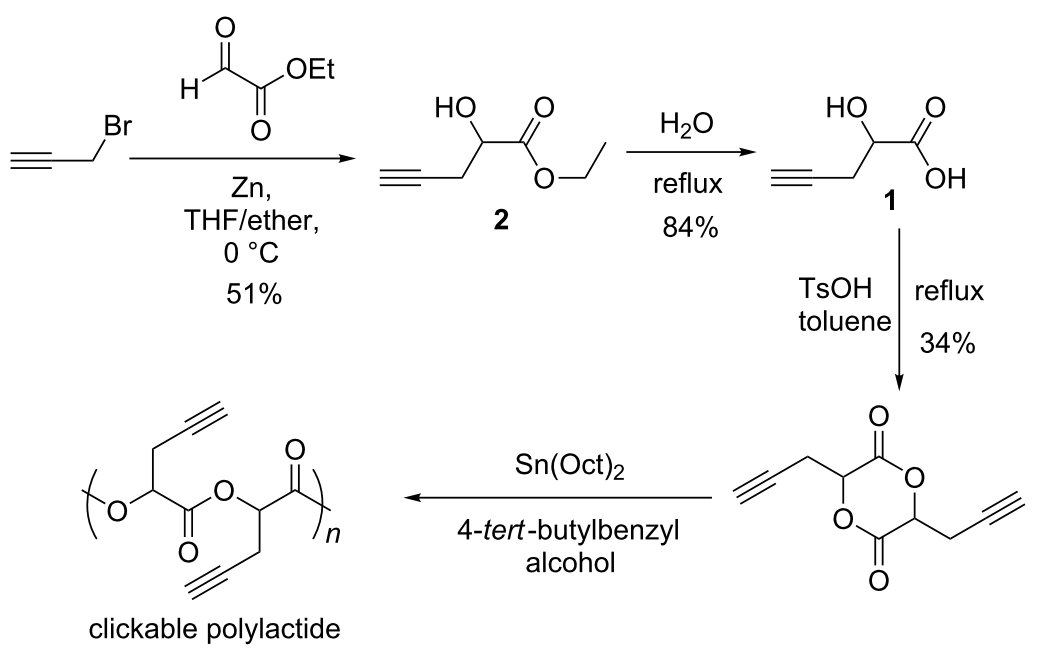

Scheme 1: Synthesis of 2-hydroxy-4-pentynoic acid (1). 
Thus, efforts were taken to develop a safe and practical synthetic route for precursor 1. Our first successful effort in the synthesis of $\mathbf{1}$ gave a good overall yield (50\%) after removal of the trimethylsilyl protecting group and hydrolysis of ester $\mathbf{3}$, generated from diethylaluminum(trimethylsilyl)acetylide and methyl glycidate (Scheme 2) [24]. Although it does not involve explosive propargyl bromide, this method requires an excess (2 equivalents) of expensive trimethylsilylacetylene [25-28] and highly flammable chemicals (butyllithium and diethylaluminum chloride) which makes this route even more costly and less attractive. Therefore, in order to provide sufficient $\mathbf{1}$ for preparing 'clickable' PLA and expand its application scope via 'click' modification in biomedical fields, an economical and safe procedure to synthesize $\mathbf{1}$ with good yield is highly desirable using simple and cheap starting materials.

Several other promising synthetic routes to precursor 1 were also proposed and examined in our group in order to find a safe and affordable procedure without using propargyl bromide. However, all attempted synthetic routes to $\mathbf{1}$ indicated in
Scheme 3 were determined not to be feasible probably due to the interruption of the ethynyl proton in the presence of organometallic reagents [29].

As discussed above, there are two important factors that should be taken into account in order to achieve a safe and economical route resulting in precursor 1: 1) a non-explosive and cheap source of acetylene building moiety; and 2) basic reaction conditions involving a low $\mathrm{pKa}(<24)$ to avoid the interruption of the ethynyl proton ( $\mathrm{pKa} \sim 24$ ) while introducing the acetylene moiety. Propargyl tosylate, prepared from propargyl alcohol and tosyl chloride, is a safe analogue of propargyl bromide with low cost. Malonate has a low $\mathrm{pKa}$ of $\sim 13$ and can be easily deprotonated and alkylated by mild bases such as sodium/potassium alkoxides without deprotonating a terminal alkyne. Conveniently, both malonate and propargyl alcohol are commercially available in bulk quantities. Herein, we report one economical and safe procedure using diethyl 2-acetamidomalonate (4) and propargyl alcohol as starting materials to synthesize 1 . The synthesis was completed via alkylation of

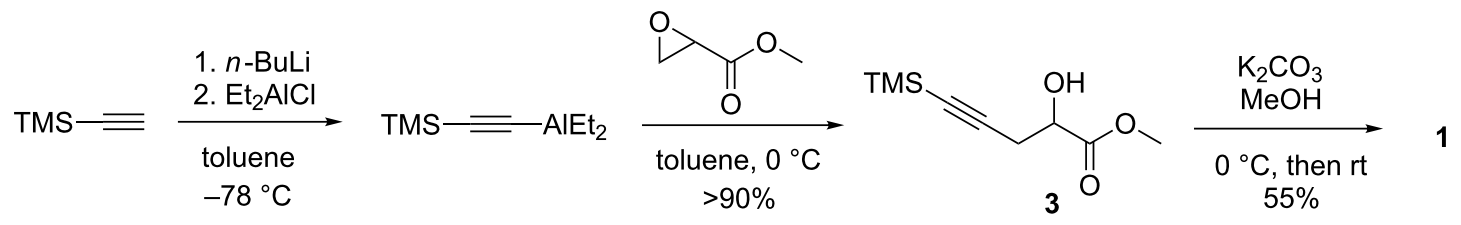

Scheme 2: Synthesis of 1 via epoxide ring opening with organoalane.

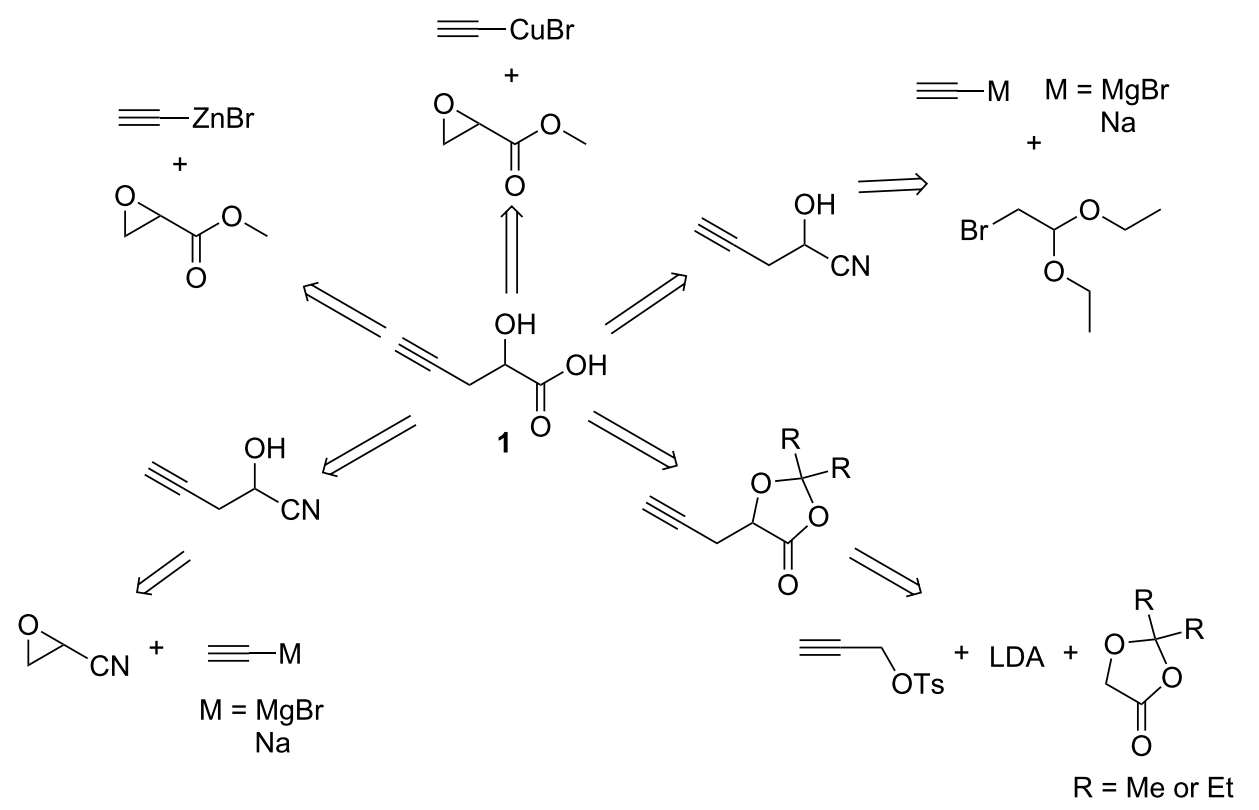


malonate $\mathbf{4}$ with propargyl tosylate followed by a one-pot fourstep sequence of hydrolysis, decarboxylation, diazotization and hydroxylation of propargylic malonate $\mathbf{5}$ without work-up of any intermediates.

\section{Results and Discussion}

The synthesis of the desired precursor 1 was straightforward and outlined in Scheme 4. Propargyl alcohol, a cheap source of an acetylene moiety, was tosylated with tosyl chloride following a modified procedure [30] to provide propargyl tosylate in high yield as a dark liquid after drying under vacuum. Diethyl 2-acetamidomalonate (4), deprotonated by potassium tert-butoxide, was alkylated in dioxane by a conventional $C$-alkylation method [31-34] with propargyl tosylate to give propargylic derivative $\mathbf{5}$. The alkylation step was optimized and it can be conducted with an enolate concentration of $\mathbf{4}$ up to $0.25 \mathrm{M}$ in dioxane (Table 1). The attempt with higher enolate concentration was not smooth due to the increased viscosity of the reaction mixture and thus low efficiency of stirring, even with a mechanical stirrer, which resulted in a messy mixture of product observed from the ${ }^{1} \mathrm{H}$ NMR spectrum of the crude reaction mixture. The $C$-alkylation of $\mathbf{4}$ in a more common solvent, THF, was found to be not suitable due to the low conversion with even a much longer reaction time (entry 3, Table 1) [31]. Under the conditions indicated in Scheme 4 and Table 1, propargylic derivative $\mathbf{5}$ was obtained in quantitative yield and with high purity after optimization, and it is not necessary to further purify $\mathbf{5}$.

Reflux of 5 in a $2 \mathrm{M}$ aqueous solution of $\mathrm{H}_{2} \mathrm{SO}_{4}$ enabled the one-pot synthesis of intermediate 6 via sequential hydrolysis of amide and esters, and decarboxylation of the resulting malonic acid. The resulting intermediate $\mathbf{6}$ was not isolated and used directly for the subsequent reaction. Notably, basic treatment of $\mathbf{5}$ as discussed in literature [31,33] would not allow conversion of 5 to $\mathbf{6}$ in a convenient one-pot manner, since more harsh basic conditions are required for carrying out amide hydrolysis of 5 . Because the following diazotization of 6 requires strong<smiles>CCOC(=O)C(NC(C)=O)C(=O)OCC</smiles><smiles>[Z]#CCO[Se]</smiles>

dioxane, reflux $99 \%$<smiles>C#CCC(O)C(=O)O</smiles>

1 solid, $49 \%$<smiles>CC#CCOC(=O)C(CI)(NC(=O)I)C(=O)OCC</smiles>

5
6

1. $\mathrm{NaNO}_{2}, 2 \mathrm{M} \mathrm{H}_{2} \mathrm{SO}_{4}$
$0{ }^{\circ} \mathrm{C}$, then rt
2. urea/HCl
3. continuous
extraction in ether

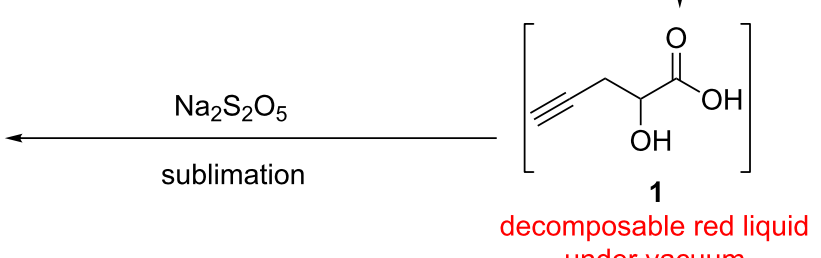

under vacuum

Scheme 4: Synthesis of 2-hydroxy-4-pentynoic acid (1) from diethyl 2-acetamidomalonate.

\begin{tabular}{|c|c|c|c|c|c|c|c|}
\hline Entry & $4 / \mathrm{mmol}$ & Solvent & $\begin{array}{c}\text { Solvent } \\
\text { volume/mL }\end{array}$ & $\begin{array}{c}\text { Concentration } \\
\text { of } 4 / \mathrm{M}\end{array}$ & $t / h$ & Conversion $^{b}$ & Yield \\
\hline 1 & 47.5 & dioxane & 475 & 0.1 & 20 & $98 \%$ & $96.0 \%$ \\
\hline 2 & 95 & dioxane & 375 & 0.25 & 24 & $99 \%$ & $99.0 \%$ \\
\hline 3 & 47.5 & THF & 475 & 0.1 & 120 & $55 \%$ & $-^{c}$ \\
\hline
\end{tabular}

apotassium tert-butoxide was dissolved in solvent (half volume of total solvent) and transferred to a solution of $\mathbf{4}$ via cannula, then propargyl tosylate was added dropwise. ${ }^{b}$ Estimated by ${ }^{1} \mathrm{H}$ NMR. ${ }^{\mathrm{c}}$ Product was not isolated. 
acidic conditions, the proper choice of acidic hydrolysis and decarboxylation of 5 in $\mathrm{H}_{2} \mathrm{SO}_{4}$ thus also further facilitated the one-pot conversion of intermediate $\mathbf{6}$ to $\mathbf{1}$ via diazotization and hydroxylation without additional work-up or isolation of 6 [3540]. In addition, proper choice of $\mathrm{H}_{2} \mathrm{SO}_{4}$ instead of $\mathrm{HCl}[41,42]$ for one-pot conversion of $\mathbf{5}$ to $\mathbf{6}$ could avoid the formation of the possible side product 2-chloro-4-pentynoic acid $[43,44]$, if chloride anions are present in the solution during the synthesis of $\mathbf{1}$ from $\mathbf{6}$ via diazotization and hydroxylation.

However, 2-hydroxy-4-pentynoic acid (1) rapidly decomposes while drying under high vacuum after continuous extraction from aqueous solution with diethyl ether (Table 2). This was not expected since acid $\mathbf{1}$ prepared by other methods did not decompose upon isolation (Scheme 2) [17]. The possible reason for this decomposition is that there might be certain oxidants present in ether phase after continuous extraction (for example, $\mathrm{HNO}_{2}$ and $\mathrm{HNO}_{3}$, verified by a rapid color change of KI-starch test paper), which destroy product $\mathbf{1}$ during concentration and drying under vacuum. And neither addition of urea (reacting with $\mathrm{HNO}_{2}$ to release $\mathrm{N}_{2}, \mathrm{CO}_{2}$ and $\mathrm{H}_{2} \mathrm{O}$ ) nor passing of crude product 1 through a short silica gel column can stop its decomposition. So three reductants were examined which presumably would remove any residual oxidants. Product 1 was not detected in ether filtrate after addition of solid $\mathrm{Na}_{2} \mathrm{SO}_{3}$ to an ether solution of 1 and filtration to remove $\mathrm{Na}_{2} \mathrm{SO}_{3}$ solid. However, acid $1 \mathrm{can}$ be recovered in lower yield after extracting the acidified aqueous solution of $\mathrm{Na}_{2} \mathrm{SO}_{3}$ with ether (Table 2). Apparently, acid 1 precipitated as its sodium salt from ether via an acid-base reaction with $\mathrm{Na}_{2} \mathrm{SO}_{3}$ ( $\mathrm{pKa}$ of 1: 3.8 [45]; $\mathrm{pKa}$ of $\left.\mathrm{H}_{2} \mathrm{SO}_{3}: 1.9,7.2\right)$. When reductant $\mathrm{Na}_{2} \mathrm{~S}_{2} \mathrm{O}_{3}$ was added to an ether solution of acid $\mathbf{1}$, a yellow solid mixture containing both acid 1 and sulfur was obtained after removal of ether under vacuum (Table 2). It is known that sodium thiosulfate decomposes to give sulfur as a solid product under acidic conditions [46]. Dissolution of this solid mixture in water, filtration to remove sulfur and subsequent removal of water in vacuo gave pure acid product $\mathbf{1}$ in $30 \%$ yield. These results indicate that it is not convenient to use solid $\mathrm{Na}_{2} \mathrm{SO}_{3}$ or $\mathrm{Na}_{2} \mathrm{~S}_{2} \mathrm{O}_{3}$ to prevent the decomposition of $\mathbf{1}$, since the addition of either salt complicated the following work-up and purification procedure. However, intact product $\mathbf{1}$ was readily obtained as a slight yellow solid in $49 \%$ yield by adding $\mathrm{Na}_{2} \mathrm{~S}_{2} \mathrm{O}_{5}$ solid to an ether solution of acid $\mathbf{1}$, followed by simple filtration, concentration and sublimation under vacuum (Table 2). The spectroscopic data of 1 were in good agreement with both authentic samples of 1 previously prepared in our lab and literature reports [1719]. This indicates that solid $\mathrm{Na}_{2} \mathrm{~S}_{2} \mathrm{O}_{5}$ removes possible oxidants and simply enables the formation of undecomposed solid product $\mathbf{1}$ after drying in vacuo. Despite the moderate yield, this procedure represents a simple, economical and safe approach to synthesize precursor $\mathbf{1}$.

\section{Conclusion}

One simple, economical and safe procedure to prepare 2-hydroxy-4-pentynoic acid (1) was developed and optimized using cheap and commercially available starting materials diethyl 2-acetamidomalonate (4) and propargyl alcohol. $C$-Alkylation of malonate 4 with propargyl tosylate in dioxane afforded propargyl derivative $\mathbf{5}$ quantitatively. The proper choice of acidic hydrolysis and decarboxylation of 5 in $2 \mathrm{M}$ $\mathrm{H}_{2} \mathrm{SO}_{4}$ enabled the synthesis of precursor 1 via a one-pot fourstep sequence of hydrolysis, decarboxylation, diazotization and hydroxylation of propargylic malonate 5 without work-up of any intermediates. Solid $\mathrm{Na}_{2} \mathrm{~S}_{2} \mathrm{O}_{5}$ was effective to remove any possible oxidants (like $\mathrm{HNO}_{2}$ and $\mathrm{HNO}_{3}$ ) to prevent decomposition of product 1 while drying under vacuum. Overall, this procedure represents a practical and economical approach to conveniently synthesize precursor 1 for preparation of 'clickable' polylactide biomaterials.

\section{Experimental General methods}

All reactions, if not stated otherwise, were performed in ovendried glassware under nitrogen atmosphere. THF and dioxane were dried over sodium/benzophenone and distilled before use. All other reagents and solvents were ACS grade and used as received unless specified. Melting points were measured on an

Table 2: 2-Hydroxy-4-pentynoic acid (1) after treatment with different reductants.

\begin{tabular}{|c|c|c|c|c|}
\hline & \multicolumn{4}{|c|}{ Reductant $^{\mathrm{a}}$} \\
\hline & None & $\mathrm{Na}_{2} \mathrm{SO}_{3}$ & $\mathrm{Na}_{2} \mathrm{~S}_{2} \mathrm{O}_{3}$ & $\mathrm{Na}_{2} \mathrm{~S}_{2} \mathrm{O}_{5}$ \\
\hline Compounds in ether phase ${ }^{b}$ & 1 & No 1 & Sulfur +1 & 1 \\
\hline Appearance of dry $1^{c}$ & Decomposition black & Light yellow solid ${ }^{d}$ & Yellow solid & Light yellow solid \\
\hline
\end{tabular}

asolid reductants were added into ether extract containing 1 and the resulting mixture was stirred. ${ }^{b}$ Compounds in ether extract after treatment with reductants. "Product 1 was obtained upon removal of ether after treatment with reductants and followed by filtration. ${ }^{\mathrm{d} P r o d u c t} \mathbf{1}$ was recovered with low yield after extracting the acidified aqueous solution of solid $\mathrm{Na}_{2} \mathrm{SO}_{3}$ with ether. 
Electrothermo ${ }^{\circledR}$ melting point apparatus. ${ }^{1} \mathrm{H}$ NMR and ${ }^{13} \mathrm{C}$ NMR were recorded on a VXR-500 MHz instrument in $\mathrm{CDCl}_{3}$ unless otherwise noted. $\mathrm{CDCl}_{3}$ was used as the internal standard for both ${ }^{1} \mathrm{H}$ NMR $(\delta=7.24)$ and ${ }^{13} \mathrm{C}$ NMR $(\delta=77.0)$

\section{Synthesis of propargyl tosylate}

A $2 \mathrm{~L}$ round bottom flask equipped with a mechanical stirrer was charged with $58 \mathrm{~mL}(1.0 \mathrm{~mol})$ of propargyl alcohol, $250 \mathrm{~g}$ $(1.30 \mathrm{~mol})$ of tosyl chloride and $1000 \mathrm{~mL}$ of diethyl ether under nitrogen. The resulting reaction mixture was cooled in an ice bath, and $\mathrm{NaOH}$ pellets $(200 \mathrm{~g}, 5.00 \mathrm{~mol})$ were added to the solution in 6 portions at $0{ }^{\circ} \mathrm{C}$ under vigorous stirring. The resulting mixture was continually stirred overnight at room temperature. The suspension was poured into cold water and the resulting aqueous layer was extracted with ether $(2 \times 250 \mathrm{~mL})$. The ether layer was combined, dried over anhydrous $\mathrm{Na}_{2} \mathrm{SO}_{4}$ and concentrated. Pure propargyl tosylate was obtained as a dark liquid $[30,47]$ in $84.0 \%$ yield $(185 \mathrm{~g})$ by drying under high vacuum (Caution: gloves are required when handling propargyl tosylate). ${ }^{1} \mathrm{H}$ NMR $\left(500 \mathrm{MHz}, \mathrm{CDCl}_{3}\right) \delta 7.76(\mathrm{~d}, J=8 \mathrm{~Hz}, 2 \mathrm{H})$, $7.30(\mathrm{~d}, J=8.5 \mathrm{~Hz}, 2 \mathrm{H}), 4.65(\mathrm{~d}, J=2.5 \mathrm{~Hz}, 2 \mathrm{H}), 2.49(\mathrm{t}, J=$ $2.5 \mathrm{~Hz}, 1 \mathrm{H}), 2.47(\mathrm{~s}, 3 \mathrm{H}) ;{ }^{13} \mathrm{C} \mathrm{NMR}\left(125 \mathrm{MHz}, \mathrm{CDCl}_{3}\right) \delta$ 145.3, 133.1, 130.0, 128.2, 77.4, 75.4, 57.44, 21.8 .

\section{Synthesis of diethyl $\alpha$-propargyl- $\alpha$-acetamido- malonate (5)}

To a solution of $105 \mathrm{~g}(0.483 \mathrm{~mol})$ of diethyl 2-acetamidomalonate (4) in $1.35 \mathrm{~L}$ of dioxane was added a slurry of $61 \mathrm{~g}$ $(0.54 \mathrm{~mol})$ of potassium tert-butoxide in $550 \mathrm{~mL}$ of dioxane dropwise via cannula over $2 \mathrm{~h}$ while stirring with a mechanical stirrer at room temperature. The resulting suspension was heated to $50{ }^{\circ} \mathrm{C}$ and stirred for another $2 \mathrm{~h}$. A solution of propargyl tosylate $(83 \mathrm{~mL}, 0.49 \mathrm{~mol})$ in $150 \mathrm{~mL}$ of dioxane was added dropwise at $50{ }^{\circ} \mathrm{C}$ over $1 \mathrm{~h}$ and the resulting mixture was brought to reflux overnight. The reaction mixture was cooled to room temperature and filtered to remove the solid. The filtrate was concentrated on rotavap and the crude product was dissolved in $1 \mathrm{~L}$ of dichloromethane. The organic layer was washed with water $(2 \times 500 \mathrm{~mL})$, decolorized with activated charcoal and dried over anhydrous $\mathrm{Na}_{2} \mathrm{SO}_{4}$. The desired product diethyl $\alpha$-propargyl- $\alpha$-acetamidomalonate (5) was obtained as a light yellow solid [31] in $99.0 \%$ yield (122 g) by solvent evaporation and drying under vacuum. Mp $85-88{ }^{\circ} \mathrm{C}$; ${ }^{1} \mathrm{H}$ NMR $\left(500 \mathrm{MHz}, \mathrm{CDCl}_{3}\right) \delta 6.91(\mathrm{~s}, 1 \mathrm{H}), 4.24(\mathrm{dd}, J=3,7.5 \mathrm{~Hz}, 4 \mathrm{H})$ $3.26(\mathrm{~d}, J=2.5 \mathrm{~Hz}, 2 \mathrm{H}), 2.04(\mathrm{~s}, 3 \mathrm{H}), 1.94(\mathrm{t}, J=2.5 \mathrm{~Hz}, 1 \mathrm{H})$, $1.24(\mathrm{t}, J=7.5 \mathrm{~Hz}, 6 \mathrm{H}) ;{ }^{13} \mathrm{C} \mathrm{NMR}\left(125 \mathrm{MHz}, \mathrm{CDCl}_{3}\right) \delta 169.6$, $166.8,78.7,71.9,65.5,63.3,24.1,23.3,14.2$.

\section{Synthesis of 2-hydroxy-4-pentynoic acid (1)}

A $3 \mathrm{~L}$ round bottom flask was charged with $110 \mathrm{~g}(0.431 \mathrm{~mol})$ of 5 and $1.2 \mathrm{~L}$ of $2 \mathrm{M} \mathrm{H}_{2} \mathrm{SO}_{4}$ and the resulting mixture was heated to reflux until full conversion of 5 to 2-amino-4pentynoic acid $(6, \sim 36 \mathrm{~h})$. The reaction mixture was used directly without further isolation. A solution of $\mathrm{NaNO}_{2}$ ( 5 equiv, $40 \%$ ) in water was added dropwise to the aqueous solution of amino acid 6 at $0{ }^{\circ} \mathrm{C}$ followed by the addition of another 3 equiv of $\mathrm{NaNO}_{2}$ in water $(40 \%)$. The resulting mixture was stirred for $40 \mathrm{~h}$ at room temperature, and urea in diluted $\mathrm{HCl}(1 \mathrm{M})$ was added dropwise until the mixture did not make potassium iodide starch test paper blue or purple. The resulting product 1 was extracted with ether using a continuous extraction apparatus. Solid $\mathrm{Na}_{2} \mathrm{~S}_{2} \mathrm{O}_{5}$ was added to ether layer and the resulting mixture was stirred until it did not turn potassium iodide starch test paper to purple. After removal of $\mathrm{Na}_{2} \mathrm{~S}_{2} \mathrm{O}_{5}$ via filtration, the ether layer was concentrated, dried and sublimated under vacuum to give $24.1 \mathrm{~g}$ of acid $\mathbf{1}$ in $49.0 \%$ yield [17]. ${ }^{1} \mathrm{H} \mathrm{NMR}\left(500 \mathrm{MHz}, \mathrm{CDCl}_{3}\right) \delta 4.35(\mathrm{t}, J=4.5 \mathrm{~Hz}$, $1 \mathrm{H}), 2.68(\mathrm{~m}, 2 \mathrm{H}), 2.08(\mathrm{t}, J=2.5 \mathrm{~Hz}, 1 \mathrm{H}) ;{ }^{13} \mathrm{C} \mathrm{NMR}$ $\left(125 \mathrm{MHz} \mathrm{CDCl}_{3}\right) \delta 177.5,77.7,71.9,68.5,24.4$.

\section{Acknowledgements}

This manuscript is in memory of our friend and colleague, Prof. Gregory L. Baker, who passed away unexpectedly while this paper was under preparation. The authors are grateful to Prof. William D. Wulff at Michigan State University for his invaluable guidance, discussions and assistance during preparation of this manuscript.

\section{References}

1. Dechy-Cabaret, O.; Martin-Vaca, B.; Bourissou, D. Chem. Rev. 2004, 104, 6147-6176. doi:10.1021/cr040002s

2. Claes, L. E.; Ignatius, A. A.; Rehm, K. E.; Scholz, C. Biomaterials 1996, 17, 1621-1626. doi:10.1016/0142-9612(95)00327-4

3. Jiang, W.; Gupta, R. K.; Deshpande, M. C.; Schwendeman, S. P. Adv. Drug Delivery Rev. 2005, 57, 391-410. doi:10.1016/j.addr.2004.09.003

4. Rancan, F.; Papakostas, D.; Hadam, S.; Hackbarth, S.; Delair, T.; Primard, C.; Verrier, B.; Sterry, W.; Blume-Peytavi, U.; Vogt, A. Pharm. Res. 2009, 26, 2027-2036. doi:10.1007/s11095-009-9919-x

5. Pan, Z.; Ding, J. Interface Focus 2012, 2, 366-377. doi:10.1098/rsfs.2011.0123

6. Mizutani, M.; Arnold, S. C.; Matsuda, T. Biomacromolecules 2002, 3, 668-675. doi:10.1021/bm0101670

7. Nederberg, F.; Bowden, T.; Hilborn, J. Macromolecules 2004, 37, 954-965. doi:10.1021/ma035433b

8. Stanford, M. J.; Dove, A. P. Macromolecules 2009, 42, 141-147. doi:10.1021/ma801977e

9. Trollsås, M.; Lee, V. Y.; Mecerreyes, D.; Löwenhielm, P.; Möller, M.; Miller, R. D.; Hedrick, J. L. Macromolecules 2000, 33, 4619-4627. doi:10.1021/ma992161x

10. Kimura, Y.; Shirotani, K.; Yamane, H.; Kitao, T. Macromolecules 1988, 21, 3338-3340. doi:10.1021/ma00189a037

11. Lutz, J.-F.; Hoth, A. Macromolecules 2006, 39, 893-896. doi:10.1021/ma0517042

12. Jiang, X.; Smith, M. R., III; Baker, G. L. Macromolecules 2008, 41, 318-324. doi:10.1021/ma070775t 
13. Jiang, X.; Vogel, E. B.; Smith, M. R., III; Baker, G. L. J. Polym. Sci., Part A: Polym. Chem. 2007, 45, 5227-5236. doi:10.1002/pola.22268

14. Castillo, J. A.; Borchmann, D. E.; Cheng, A. Y.; Wang, Y.; Hu, C.; García, A. J.; Weck, M. Macromolecules 2012, 45, 62-69. doi:10.1021/ma2016387

15. Mecerreyes, D.; Miller, R. D.; Hedrick, J. L.; Detrembleur, C.; Jerome, R. J. Polym. Sci., Part A: Polym. Chem. 2000, 38, 870-875. doi:10.1002/(SICI)1099-0518(20000301)38:5<870::AID-POLA11>3.0.C 0;2-7

16. Rubinshtein, M.; James, C. R.; Young, J. L.; Ma, Y. J.; Kobayashi, Y.; Gianneschi, N. C.; Yang, J. Org. Lett. 2010, 12, 3560-3563. doi:10.1021/ol101433v

17. Jiang, X.; Vogel, E. B.; Smith, M. R., III; Baker, G. L. Macromolecules 2008, 41, 1937-1944. doi:10.1021/ma7027962

18. Yu, Y.; Zou, J.; Yu, L.; Ji, W.; Li, Y.; Law, W.-C.; Cheng, C. Macromolecules 2011, 44, 4793-4800. doi:10.1021/ma2005102

19. Coumes, F.; Darcos, V.; Domurado, D.; Li, S.; Coudane, J. Polym. Chem. 2013, 4, 3705-3713. doi:10.1039/c3py00375b

20. Kolb, H. C.; Finn, M. G.; Sharpless, K. B. Angew. Chem. 2001, 113, 2056-2075 doi:10.1002/1521-3757(20010601)113:11<2056::AID-ANGE2056>3.0. $\mathrm{CO} ; 2-\mathrm{W}$

Angew. Chem., Int. Ed. 2001, 40, 2004-2021. doi:10.1002/1521-3773(20010601)40:11<2004::AID-ANIE2004>3.0.CO ;2-5

21. Forshey, D. R.; Cooper, J. C.; Martindill, G. H.; Kuchta, J. M. Fire Technol. 1969, 5, 100-111. doi:10.1007/BF02591588

22. Nwokogu, G. C. Propargylmagnesium Bromide. e-EROS Encyclopedia of Reagents for Organic Synthesis; Wiley, 2001.

23. Wuts, P. G. M.; Greene, T. W. Protection for the Hydroxyl Group, Including 1,2- and 1,3-Diols. Greene's Protective Groups in Organic Synthesis, 4th ed.; John Wiley \& Sons: Hoboken, NJ, 2006; pp 99 ff. doi:10.1002/9780470053485.ch2

24. Roush, W. R.; Blizzard, T. A.; Basha, F. Z. Tetrahedron Lett. 1982, 23 , 2331-2334. doi:10.1016/S0040-4039(00)87334-7

25. Suzuki, T.; Saimoto, H.; Tomioka, H.; Oshima, K.; Nozaki, H. Tetrahedron Lett. 1982, 23, 3597-3600. doi:10.1016/S0040-4039(00)87680-7

26. Akita, H.; Matsukura, H.; Oishil, T. Tetrahedron Lett. 1986, 27, 5397-5400. doi:10.1016/S0040-4039(00)85221-1

27. Larcheveque, M.; Peit, Y. Bull. Soc. Chim. Fr. 1986, 130-139.

28. Murray, T. F.; Samsel, E. G.; Varma, V.; Norton, J. R. J. Am. Chem. Soc. 1981, 103, 7520-7528. doi:10.1021/ja00415a020

29. The routes shown in Scheme 3 are unpublished and will not be presented in this paper.

30. Srinivasan, R.; Uttamchandani, M.; Yao, S. Q. Org. Lett. 2006, 8, 713-716. doi:10.1021/ol052895w

31. Brea, R. J.; López-Deber, M. P.; Castedo, L.; Granja, J. R. J. Org. Chem. 2006, 71, 7870-7873. doi:10.1021/jo061300n

32. Baldwin, J. E.; Bradley, M.; Abbott, S. D.; Adlington, R. M. Tetrahedron 1991, 47, 5309-5328. doi:10.1016/S0040-4020(01)87142-8

33. van Hest, J. C. M.; Kiick, K. L.; Tirrell, D. A. J. Am. Chem. Soc. 2000, 122, 1282-1288. doi:10.1021/ja992749j

34. Young, D. D.; Torres-Kolbus, J.; Deiters, A. Bioorg. Med. Chem. Lett. 2008, 18, 5478-5480. doi:10.1016/j.bmcl.2008.09.025

35. Pettit, G. R.; Hu, S.; Knight, J. C.; Chapuis, J.-C. J. Nat. Prod. 2009, 72, 372-379. doi:10.1021/np800607x

36. Cahiez, G.; Metais, E. Tetrahedron Lett. 1995, 36, 6449-6452. doi:10.1016/0040-4039(95)01289-T
37. Dragovich, P. S.; Prins, T. J.; Zhou, R.; Johnson, T. O.; Hua, Y.; Luu, H. T.; Sakata, S. K.; Brown, E. L.; Maldonado, F. C.; Tuntland, T.; Lee, C. A.; Fuhrman, S. A.; Zalman, L. S.; Patick, A. K.;

Matthews, D. A.; Wu, E. Y.; Guo, M.; Borer, B. C.; Nayyar, N. K.; Moran, T.; Chen, L.; Rejto, P. A.; Rose, P. W.; Guzman, M. C.; Dovalsantos, E. Z.; Lee, S.; McGee, K.; Mohajeri, M.; Liese, A.; Tao, J.; Kosa, M. B.; Liu, B.; Batugo, M. R.; Gleeson, J.-P. R.; Wu, Z. P.; Liu, J.; Meador, J. W., III; Ferre, R. A. J. Med. Chem. 2003, 46, 4572-4585. doi:10.1021/jm030166l

38. Feifel, S. C.; Schmiederer, T.; Hornbogen, T.; Berg, H.; Süssmuth, R. D.; Zocher, R. ChemBioChem 2007, 8, 1767-1770. doi:10.1002/cbic.200700377

39. Müller, J.; Feifel, S. C.; Schmiederer, T.; Zocher, R.; Süssmuth, R. D. ChemBioChem 2009, 10, 323-328. doi:10.1002/cbic.200800539

40. Matthes, D.; Richter, L.; Müller, J.; Denisiuk, A.; Feifel, S. C.; Xu, Y.; Espinosa-Artiles, P.; Süssmuth, R. D.; Molnár, I. Chem. Commun. 2012, 48, 5674-5676. doi:10.1039/c2cc31669b

41. Cali, P.; Begtrup, M. Synthesis 2002, 63-66. doi:10.1055/s-2002-19301

42. Nejman, M.; Śliwińska, A.; Zwierzak, A. Tetrahedron 2005, 61, 8536-8541. doi:10.1016/j.tet.2005.04.077

43. Fu, S.-C. J.; Birnbaum, S. M.; Greenstein, J. P. J. Am. Chem. Soc. 1954, 76, 6054-6058. doi:10.1021/ja01652a057

44. Koppenhoefer, B.; Schurig, V. Org. Synth. 1993, Coll. Vol. 8, 119; 1988, 66, 151.

45. Deprez, P. Alpha-hydroxy acids: chemistry, $\mathrm{pH}$ and $\mathrm{pK}_{\mathrm{a}}$, and mechanism of action. Textbook of Chemical Peels. Superficial, Medium, and Deep Peels in Cosmetic Practice, 1st ed.; Informa UK: London, U.K., 2007.

46. Kerker, M. J. Chem. Phys. 1951, 19, 1324-1325. doi:10.1063/1.1748044

47. Asano, K.; Matsubara, S. Org. Lett. 2009, 11, 1757-1759. doi:10.1021/ol900125y

\section{License and Terms}

This is an Open Access article under the terms of the Creative Commons Attribution License (http://creativecommons.org/licenses/by/2.0), which permits unrestricted use, distribution, and reproduction in any medium, provided the original work is properly cited.

The license is subject to the Beilstein Journal of Organic Chemistry terms and conditions:

(http://www.beilstein-journals.org/bjoc)

The definitive version of this article is the electronic one which can be found at: doi:10.3762/bjoc.10.139 